\title{
Molecular Marker-Assisted Backcrossing of Anthracnose Resistance Genes into Common Beans (Phaseolus vulgaris L.) Varieties
}

\author{
Annuarite Uwera1,2, John Nzungize Rusagara3 ${ }^{3}$, Susan Nchimbi Msolla1, \\ Augustine Musoni ${ }^{2}$, Teshale Assefa ${ }^{4 *}$
}

${ }^{1}$ Sokoine University of Agriculture, Morogoro, Tanzania

${ }^{2}$ Rwanda Agriculture and Animal Resources Development Board, Kigali, Rwanda

${ }^{3}$ International Crops Research Institute for the Semi-Arid Tropics, Bamako, Mali

${ }^{4}$ Alliance Biodiversity International and CIAT, Arusha, Tanzania

Email: `teshale.mamo@cgiar.org

How to cite this paper: Uwera, A., Rusagara, J.N., Msolla, S.N., Musoni, A. and Assefa, T. (2021) Molecular Marker-Assisted Backcrossing of Anthracnose Resistance Genes into Common Beans (Phaseolus vulgaris L.) Varieties. American Journal of Plant Sciences, 12, 771-781.

https://doi.org/10.4236/ajps.2021.125053

Received: April 9, 2021

Accepted: May 23, 2021

Published: May 26, 2021

Copyright $\odot 2021$ by author(s) and Scientific Research Publishing Inc. This work is licensed under the Creative Commons Attribution International License (CC BY 4.0).

http://creativecommons.org/licenses/by/4.0/

\begin{abstract}
Anthracnose, caused by Colletotrichum lindemuthianum, is a major disease of common bean and results in high yield loss. Due to the high degree of pathogenic variability of the fungus and the continual emergence of new races, genetic resistance in the host is not durable. Gene pyramiding using Marker Assisted Selection (MAS) is proposed as a viable approach to improve the durability of major genes conditioning resistance to anthracnose. In this study a common bean line Urugezi x AND 1062 susceptible to anthracnose but already improved for Pythium root rot resistance was improved for anthracnose resistance through a backcross breeding program. Genotypic selection was done in Rubilizi laboratory in Kigali, Rwanada whereas phenotypic selection was conducted in an anthracnose hotspot at Rwerere, a research Centre of the Rwanda Agricultural and Animal Resources Development Board (RAB). Analysis of variance for effect of bean varieties and anthracnose isolates on disease expression showed significant differences $(p<0.001)$ among varieties and isolates and for the interaction between isolates and varieties. Developed $\mathrm{BC}_{2} \mathrm{~F}_{1}$ plants were $41 \%$ of them resistant and $59 \%$ susceptible to anthracnose. However, the observed proportion of 26 resistants and 37 susceptible in $\mathrm{BC}_{2} \mathrm{~F}_{1}$ plants didn't fit the goodness of fit of the expected proportion of 75 resistants to 25 susceptible. Only $41 \%$ of $\mathrm{BC}_{2} \mathrm{~F}_{1}$ plants inherited the resistance genes and were phenotypically resistant. Presence of SCAR-markers, SAB3 and SBB14, in the developed resistant lines $h$ suggested successful resistance transfer of anthracnose resistance genes.
\end{abstract}




\section{Keywords}

Anthracnose, Common Bean, Resistance Genes, Pythium Root Rot

\section{Introduction}

Bean anthracnose causes a significant yield reduction thereby causing food shortages and loss of income to Rwandan farmers. Anthracnose in common bean is caused by Colletotrichum lindemuthianum, which is one of the most destructive diseases of common bean. The pathogen for anthracnose is greatly variable and it has co-evolved with Middle American and Andean gene races [1] [2]. The disease is reportedly one of the most important and widely distributed throughout the world.

Anthracnose causes particularly severe economic losses in Latin America, Central and Eastern Africa. Yield losses of $95 \%$ have been recorded in Colombia and of over 92\% in Malawi. Bean Anthracnose can cause losses of up to 100\% particularly on susceptible varieties under favourable conditions [3] [1], and also when infected seed is used. Production is reduced because of poor seed germination, poor seedling vigour, and low yields.

In Rwanda, the bean anthracnose can lead to total yield losses when susceptible varieties are grown under favourable pathogen environmental conditions [4]. Breeding for anthracnose resistance can be a positive answer for reducing losses caused by anthracnose disease in common bean.

More than 10 different anthracnose resistance genes have been identified in a number of bean varieties [5]. Cultivar G2333, a climber released in the great lakes region as Umubano and in Uganda as NABE 10C carries three complementary genes; $\mathrm{Co}-4^{2}, \mathrm{Co}-5$ and $\mathrm{Co}-7$ [5] and so far is the most anthracnose resistant variety. It is currently the best choice as a donor for anthracnose resistance genes. Fortunately, enough, this cultivar is widely adapted and yields heavily [6]. $C o-4^{2}$ confers the broadest resistance to most known $C$. lindemuthianum isolates. Introgression of genes for resistance to anthracnose into susceptible bean varieties could be a strong response to anthracnose. Therefore, the objective of this study was to introgress genes for anthracnose resistance in a common bean line with Pythium root rot resistance and to develop a common bean line resistant against anthracnose and Pythium root rot.

\section{Materials and Methods}

\subsection{Plant Materials}

This study included four varieties such as RWV 3006, Gasilida, RWR 2355 and G2333 along with Urugezi x AND 1062. The varieties RWV 3006, Gasilida and RWR 2355 are of white, red and red mottled bean types. They are mostly grown in the study area where anthracnose is a major disease problem. G2333 is a small red market class type is mainly grown by farmers in most part of Rwanda This 
Cultivar (G2333), is also a climbing bean type released in the great lakes region as Umubano and in Uganda as NABE 10C, which carries three complementary genes; $\mathrm{Co}-4^{2}, \mathrm{Co}-5$ and $\mathrm{Co}-7$ [6] and so far it is the most anthracnose resistant variety. Urugezi $\times$ AND 1062, is a red mottled bean line already improved for Pythium root rot resistance by Nzungize et al. [7] and is susceptible to anthracnose. These genotypes were obtained from the gene bank at Rwanda Agricultural and Animal Resources Development Board (RAB).

Urugezi $\times$ AND 1062 used as recurrent parent and was crossed with G2333 which is used as donor parent and source of anthracnose resistance genes $\mathrm{Co}-4^{2}$ and $C o-5$ in 2016 at RAB. Then $\mathrm{F}_{1}$ was backcrossed to Urugezi $\times$ AND 1062 to generate $\mathrm{BC}_{1} \mathrm{~F}_{1}$ which was also backcrossed to Urugezi $\times$ AND 1062 to generate $\mathrm{BC}_{2} \mathrm{~F}_{1}$ segregating population with anthracnose resistance and possessing commercial quality (red mottled market class) using Marker Assisted Selection.

\subsection{Isolates Collection and Inoculum Preparation}

Fifty isolates used in this study were collected in the northern and southern agricultural zones of Rwanda, from the most anthracnose hotspot areas. Potato Dextrose Agar (PDA) and Marthur media were prepared following the International Center for Tropical Agriculture (CIAT) protocol. Small portions of bean pods and leaves with anthracnose symptoms were plated on both media and incubated upside down to grow at the temperature of $24^{\circ} \mathrm{C}$, then incubated for 5 days. Then after single spore culture was done after one month, from old isolates which had shown anthracnose spores features under the microscope. Twelve anthracnose isolates were identified (named as, a, b, c, d, e, f, g, h, i, j, k, l, and m used control-which is distilled water) and inoculum per isolate was prepared at a concentration of $1.2 \times 10^{6}$ spores per millilitre. In order to confirm the most virulent among the twelve, three common bean varieties known to be high and less susceptible to anthracnose were screened by the twelve isolates. Inoculation of bean seedlings was done by applying the spore suspension with paint brush starting from the abaxial to the adaxial sides of primary leaves and the first trifoliate leaf until run off was evident. Inoculated plants were covered with a transparent plastic bag for 48 hours in order to maintain a relative humidity of approximately $>92 \%$. Two days later, the transparent plastic bag was removed. Watering was done twice a day then [8] scale was used to evaluate common bean with anthracnose symptoms. Plants with scores of 1 to 3 were considered as resistant, whereas those with scores of 4 to 9 were rated as mildly to severely susceptible.

\subsection{Evaluation of Segregating $\mathrm{BC}_{2} \mathrm{~F}_{1}$ Plants}

The experiment was carried out in Rwerere located at Latitude $1^{\circ} 36^{\prime} 27^{\prime \prime S}$ and Longitude $29^{\circ} 19^{\prime} 52^{\prime \prime} \mathrm{E}$. Rwerere is one of seven sectors of Burera District. Its average altitude reaches 2, 100 meter above sea level. District's climate is humid, with two dry seasons and two rainy seasons: a short dry season taking place in mid-December till February; a long rainy season going from March till midJune; a long dry season from June till September; and a short rainy season going 
from mid-September till December. Yearly rains reach 1, $400 \mathrm{~mm}$, whilst the temperature can go from $9^{\circ} \mathrm{C}$ to $29^{\circ} \mathrm{C}$ [9].

A split plot experimental design with three replications was used in this study. Twelve isolates and one control (sterile distilled water free of inoculum) were used to screen three common bean susceptible varieties (RWV 3006, RWR 2355 and Gasilida) in order to identify the most virulent isolate which would then be used to screen developed sixty three $\mathrm{BC}_{2} \mathrm{~F}_{1}$ plants with resistance to anthracnose. In a screen house, ten plants were planted per row with a spacing of $25 \mathrm{~cm}$ between rows and $20 \mathrm{~cm}$ between plants. Inoculation of bean seedlings was performed in a screen house by applying the spore suspension with paintbrush starting from the abaxial to the adaxial sides of primary leaves and the first trifoliate leaf until run off was evident. Inoculated plants were covered with a transparent plastic bag for 48 hours in order to maintain a relative humidity of approximately $>92 \%$. Two days later, the transparent plastic bag was removed. Watering was done once a day within a period of $7-10$ days then disease reaction was evaluated 10 days after inoculation using 1 - 9 CIAT scale.

\subsection{DNA Extraction and Amplification}

Whatman FTA protocol [10] was used for DNA extraction. DNA was extracted from young leaves collected from 2 weeks old plants on FTA cards. Bean leaves were crashed on the FTA cards till the juice (chlorophyll) appeared on the opposite side of the FTA card. Then the FTA cards were dried at room temperature before processing DNA extraction. For each sample $2 \mathrm{~mm}$ diameter punch was taken off from the part of the FTA card, washed two times with FTA purification reagent, washed again with $1 \mathrm{X}$ TE Buffer (10mM Tris- $\mathrm{HCl}, 0.1 \mathrm{mM}$ EDTA, $\mathrm{pH}$ 8.0) till when the disc looked clear free of chlorophyll. At this stage, the discs were dried at room temperature and were ready for PCR. To get amplified genomic DNA, Polymerase Chain Reaction (PCR) was performed. In this study, two SCAR markers (SBB14 a co-dominant marker for $\mathrm{Co}-4^{2}$ an anthracnose resistance gene which amplifies 1150 - $1050 \mathrm{bp}$, and SAB3 a marker for $\mathrm{Co}-5$ also another anthracnose resistance gene, it amplifies $400 \mathrm{bp}$ ) were used. The total volume of the reaction was $25 \mu \mathrm{l}$ composed of a molecular marker with a forward primer, $1 \mu \mathrm{l}$ and reverse primer, $1 \mu \mathrm{l}$, PCR water, $23 \mu \mathrm{l}$, and a disc containing DNA which is considered to contribute $0 \mu \mathrm{l}$. All the mentioned items were mixed in a PCR tube containing a bead ready for PCR then the PCR was performed. The PCR conditions included an initial denaturation at $94^{\circ} \mathrm{C}$ for 5 minutes followed by 35 amplification cycles and each cycle consisted of one denaturation step at $94^{\circ} \mathrm{C}$ for 20 seconds, one annealing step at $63^{\circ} \mathrm{C}$ for 40 seconds and one extension step at $72^{\circ} \mathrm{C}$ for 1 minute then all the three steps were followed by the last extension step at $72^{\circ} \mathrm{C}$ for 7 minutes. Then, PCR products mixed with loading dye were loaded in the wells of $1.2 \%$ agarose gel and the gel was run at 100 volts for one hour. Then the gel was removed from the tray and put under UV light and photographed. 


\subsection{Data Analysis}

A split plot experimental design was used in field experiment. Molecular and phenotypic data were analyzed using a statistical package SAS 9.2 for laboratory and field experiments. Analysis of variance was done and means separation was performed using Duncan Multiple Range Test (DMRT).

\section{Results}

\subsection{Evaluation of Anthracnose Symptoms under Field Conditions}

Analysis of variance revealed that the highly significant was found for the beans varieties and the anthracnose isolates at $\mathrm{p}<0.01$ (Table 1 ). Significant interaction was observed between bean varieties and isolates (Table 1).

Table 1. Analyze of variance for effect of bean varieties and anthracnose isolates on disease expression.

\begin{tabular}{cccccc}
\hline Source & Degree of Freedom & Sum of Squares & Mean Square & F Value & $\operatorname{Pr}>$ F \\
\hline Variety & 2 & 67.71914530 & 33.85957265 & 60.40 & $<0.0001$ \\
Isolate & 12 & 34.12769231 & 2.84397436 & 5.07 & $<0.0001$ \\
Variety * isolate & 24 & 25.11641026 & 1.04651709 & 1.87 & 0.0209 \\
\hline
\end{tabular}

$\mathrm{R}^{2}=0.74 ; \mathrm{C} . \mathrm{V}=35$. Probability level at 0.05 and 0.01 .

The mean separation was performed using Duncan Multiple Range Test (DMRT). Results showed isolate 1 and e to be the most virulent in inducing more anthracnose symptoms on the three tested common bean varieties, followed by isolates $d, k, a, g, j, c$ and $h$, while isolates $b, f, i$ and $m$ being the isolates to induce very few symptoms on the three varieties as it is indicated in Table 2.

Table 2. Mean separation of bean varieties and bean isolates.

\begin{tabular}{|c|c|c|c|}
\hline & & Average & $P$ value \\
\hline & RWV 3006 & $2.0^{\mathrm{b}}$ & $<0.0001$ \\
\hline \multirow[t]{8}{*}{ Variety } & RWR 2355 & $3.1^{\mathrm{a}}$ & \\
\hline & Gasilida & $1.2^{\mathrm{c}}$ & \\
\hline & 1 & $3.4^{\mathrm{a}}$ & \\
\hline & $\mathrm{e}$ & $2.7^{\mathrm{ab}}$ & \\
\hline & $\mathrm{d}$ & $2.3^{\mathrm{bc}}$ & \\
\hline & $\mathrm{k}$ & $2.3^{\mathrm{bc}}$ & \\
\hline & $\mathrm{a}$ & $2.2^{\mathrm{bc}}$ & $<0.0001$ \\
\hline & $\mathrm{g}$ & $2.1^{\mathrm{bc}}$ & \\
\hline \multirow[t]{7}{*}{ Isolate identity } & j & $2.0^{\mathrm{bc}}$ & \\
\hline & c & $1.9^{\mathrm{bc}}$ & \\
\hline & $\mathrm{h}$ & $1.9^{\mathrm{bc}}$ & \\
\hline & $\mathrm{b}$ & $1.8^{\mathrm{c}}$ & \\
\hline & $\mathrm{f}$ & $1.8^{\mathrm{c}}$ & \\
\hline & $\mathrm{i}$ & $1.6^{\mathrm{cd}}$ & \\
\hline & $\mathrm{m}$ & $1.0^{\mathrm{cd}}$ & \\
\hline
\end{tabular}

a, b, c, d, e, f, g, h, i, j, k, l, m, are anthracnose isolates, Duncan multiple range test ranking, and Probability level of 0.01 . 
The low means of isolates shown in Table 2 might be due to the very few symptoms observed on many plants and significant symptoms on some plants. Also, attributed disease score was between 1 - 4 than 5 - 7 according to the recorded scores. And many of the isolates were less virulent at the time of data collection; probably, at the time of inoculation, conditions for disease development were not too suitable for good disease expression as after some days after the scoring, there was an observation in disease severity increase according to the observation made.

Mean separation of bean varieties and bean isolates from ANOVA has shown RWR 2355 to have been attacked by all the twelve isolates followed by RWV 3006, while Gasilida was the less attacked variety. Also, isolate 1 has shown a high mean comparatively to other isolates.

\subsection{Genotyping of the Segregating Population $\left(\mathrm{BC}_{1} \mathrm{~F}_{1}\right.$ and $\left.\mathrm{BC}_{2} \mathrm{~F}_{1}\right)$}

A total number of $63 \mathrm{BC}_{2} \mathrm{~F}_{1}$ plants were genetically screened for the presence or absence of anthracnose resistance genes $C o-5$ and $C o-4^{2}$, using SBB14 and SAB 3 molecular markers (Figure 1 and Figure 2). SAB3 gave $33 \%$ of positive reactions and $\mathrm{SBB} 14$ had $44 \%$ of positive reactions in $\mathrm{BC}_{2} \mathrm{~F}_{1}$ progeny.
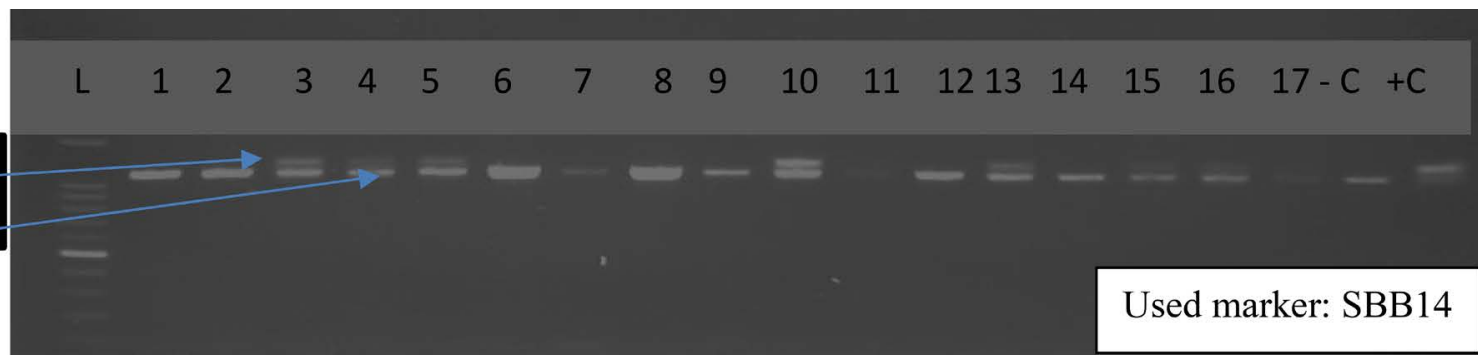

Lanes $3,4,5,10,13,15$ and 16: progenies with the SBB14 marker, tagging the Co- $4^{2}$ gene; L: 1 bp marker; -C: susceptible variety Urugezi $\times$ AND $1062 ;+C$ : resistant donor, G2333.

Figure 1. Selection of $\mathrm{BC}_{2} \mathrm{~F}_{1}$ plants using marker assisted selection.

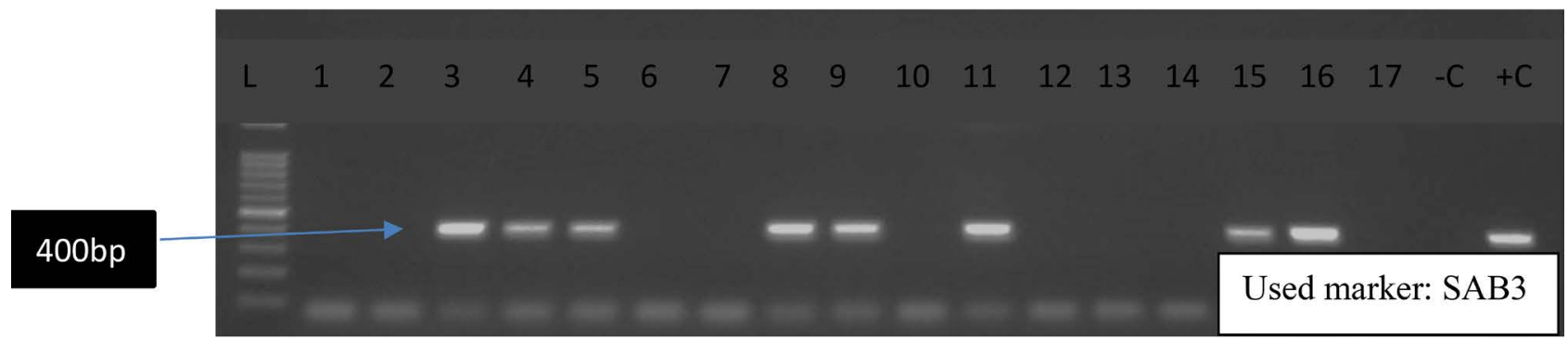

Lanes 3, 4, 5, 8, 9, 11, 15 and 16: progenies with the SAB3 marker, tagging the Co-5 gene; L: 1 bp marker; C-: Susceptible variety, Urugezi $\times$ AND1062; C+: resistant donor, G2333.

Figure 2. Selection of $\mathrm{BC}_{2} \mathrm{~F}_{1}$ plants using marker assisted selection.

Among $63 \mathrm{BC}_{2} \mathrm{~F}_{1}$ plants screened genetically and phenotypically for anthracnose resistance only 26 inherited the resistance genes and were phenotypically resistant among them 9 plants had $\mathrm{Co}-4^{2}$ and $\mathrm{Co} 5$ genes, 6 had $\mathrm{Co}-4^{2}$ and 5 had $\mathrm{Co}-5$, then 6 had no resistance gene (Figure 3). 


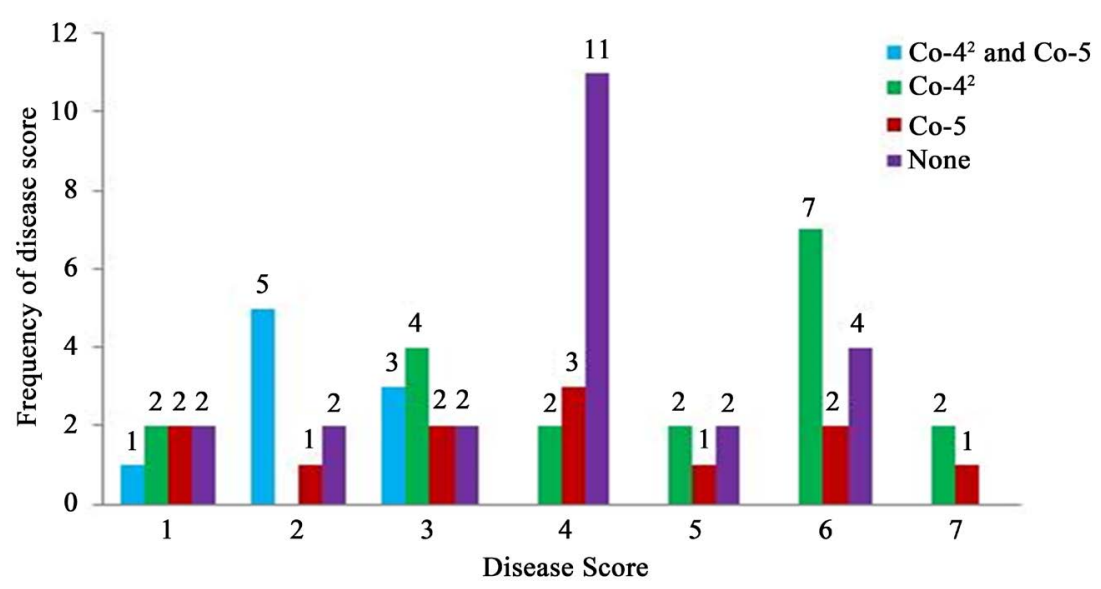

Figure 3. Inherited anthracnose resistance genes (based on marker presence) with their frequency in segregating $\mathrm{BC}_{2} \mathrm{~F}_{1}$ plants.

Thirty-seven plants were moderately resistant and susceptible. Among them 13 plants inherited the $\mathrm{Co}-4^{2}$ resistance gene but were phenotypically susceptible, 7 plants had $C o-5$ resistance gene and were also phenotypically susceptible and 17 plants had not either $\mathrm{Co}-4^{2}$ or $\mathrm{Co}-5$ resistance genes and were phenotypically susceptible. The effect of recombination had happened in some $\mathrm{BC}_{2} \mathrm{~F}_{1}$ plants with resistance genes but showing anthracnose symptoms. The same effect might have also occurred within the plants without $\mathrm{Co}-4^{2}$ and $\mathrm{Co}-5$ resistance genes and free of anthracnose symptoms.

Considering genotypic and phenotypic resistance levels in $\mathrm{BC}_{2} \mathrm{~F}_{1}$ plants, plants with $\mathrm{Co}-4^{2}$ and $\mathrm{Co}-5$ were $100 \%$ resistant, plants with only $\mathrm{Co}-4^{2}$ genes were $31.6 \%$ and $68.4 \%$ susceptible respectively. Plants with $\mathrm{Co}-5$ gene were $41.7 \%$ resistant and $58.33 \%$ susceptible (Figure 4 ).

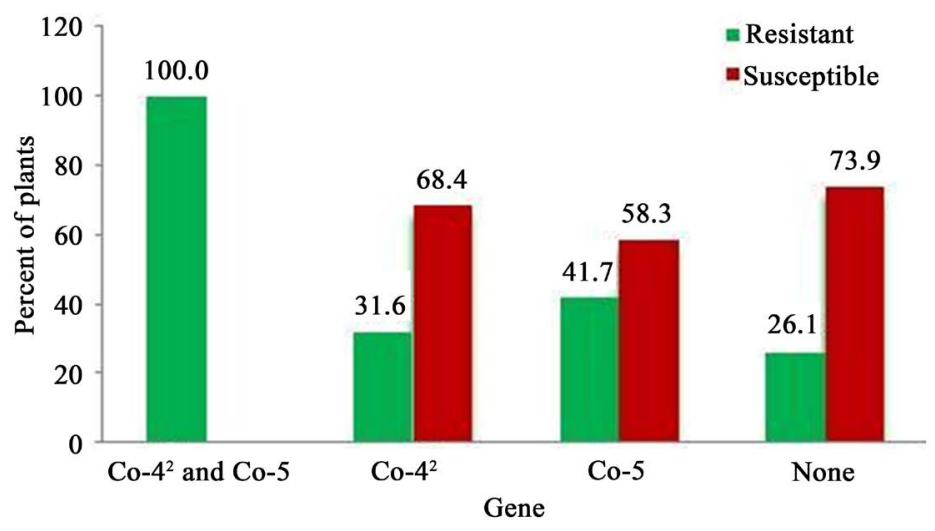

Figure 4. Resistance level of $\mathrm{BC}_{2} \mathrm{~F}_{1}$ plants with association of gene groups and disease scores.

Genetic analysis of $\mathrm{BC}_{2} \mathrm{~F}_{1}$ progenies shown that observed frequencies for resistant and susceptible progeny from the cross (Urugezi $\times$ AND1062) $\times$ G2333 that they were significantly different from the expected frequencies of 75 resistant and 25 susceptible (Table 3 ). 
Table 3. Chi square test of $\mathrm{BC}_{2} \mathrm{~F}_{1}$ screened with SCAR markers.

\begin{tabular}{cccccc}
\hline \multirow{2}{*}{ Generation } & \multicolumn{2}{c}{ No. Plants } & Expected ratio & $\chi^{2}$ & P \\
\cline { 2 - 3 } & Resistant & Susceptible & & - & - \\
\hline $\mathrm{P} 1$ & 40 & 0 & - & - & - \\
$\mathrm{P} 2$ & 0 & 30 & - & 4.45 & 0.035 \\
$\mathrm{BC}_{2} \mathrm{~F}_{1}$ & 40 & 23 & $3: 1$ & \\
\hline
\end{tabular}

$\mathrm{P} 1$ : parent 1, P2-parent 2, $\mathrm{P}$ probability level at 0.05 .

Chi-square test of $\mathrm{BC}_{2} \mathrm{~F}_{1}$ progeny for the presence/absence of $\mathrm{Co}-4^{2}$ and $\mathrm{Co}-5$ genes shown that observed proportion of resistant to susceptible progeny from the cross (Urugezi $\times$ AND1062) $\times$ G2333 was significantly different $(\mathrm{p}<0.05)$ from the expected proportion of 75 resistant to 25 susceptible as shown in Table 3. Means that the observed ratio didn't fit to the goodness of fit of 3:1 which was expected to fit in.

$\mathrm{BC}_{2} \mathrm{~F}_{1}$ progeny was screened genetically for the presence or the absence of the genes and phenotypically for disease reaction using 1 - 9 scores. Combined observed genotypic and phenotypic data have shown that the proportion observed was highly statistically different (smaller to the expected $3: 1$ ratio) $(\mathrm{p}<0.0001)$ (Table 4).

Table 4. Chi square test of $\mathrm{BC}_{2} \mathrm{~F}_{1}$ plants screened genetically and phenotypically for anthracnose resistance.

\begin{tabular}{cccccc}
\hline \multirow{2}{*}{ Generation } & \multicolumn{2}{c}{ No. Plants } & Expected ratio & $\chi^{2}$ & P \\
\cline { 2 - 5 } & Resistant & Susceptible & & \\
\hline $\mathrm{P} 1$ & 40 & 0 & - & - & - \\
$\mathrm{P} 2$ & 0 & 30 & - & - & - \\
$\mathrm{BC}_{2} \mathrm{~F}_{1}$ & 26 & 37 & $3: 1$ & 38.23 & $<0.0001$ \\
\hline
\end{tabular}

P1: parent 1, P2-parent 2, P probability level at 0.05 .

\section{Discussion}

The results obtained from the screening experiment of three common bean varieties by twelve anthracnose isolates and one control revealed that; Mean separation from analysis of variance was showed RWR 2355 bean variety to be the most susceptible to the used anthracnose isolates followed by RWV 3006, while Gasilida was the most resistant variety. In addition, mean separation from analysis of variance also shown that isolate 1 and e to be the most virulent isolates, followed by isolates $\mathrm{d}, \mathrm{k}, \mathrm{a}, \mathrm{g}, \mathrm{j}, \mathrm{c}$ and $\mathrm{h}$, while isolates $\mathrm{f}$ and $\mathrm{i}$ and $\mathrm{m}$ (distilled water) used as a control were the least virulent. Obtained results confirmed the presence of susceptible varieties and virulent isolates in the study region. Therefore, the combination of major genes if properly deployed after studying the population structure of the pathogen and its resistance spectrum should be of immense importance [11]. Balardin and Kelly [12] proposed pyramiding ge- 
netically diverse resistance genes and deploying different gene combinations in different regions as the most practical and realistic approach to provide effective long term anthracnose resistance.

On the other hand $\mathrm{BC}_{2} \mathrm{~F}_{1}$ plants were tested with the isolate $\mathrm{l}$ identified as the most virulent isolate among the collected isolates. Based on the response from combined genetic and phenotypic screening, the plants were classified as susceptible $(58.7 \%)$ and resistant $(41.3 \%)$. This method of screening varieties has been used by many other researchers in common bean and found to be the most suitable one [13].

In this study, the fact that the obtained result from genotypic and phenotypic data of $\mathrm{BC}_{1} \mathrm{~F}_{1}$ and $\mathrm{BC}_{2} \mathrm{~F}_{1}$ plants was smaller to the expected ratio might be due to many of the improved plants which inherited either $\mathrm{Co}-4^{2}$ or $\mathrm{Co}-5$ anthracnose resistance genes when the expectation was to get more plants with the two targeted genes. Plants with one or another resistance gene were resistant others not resistant to the artificial inoculation. Also, in most cases, however, bean cultivars will be resistant to some races but not to others [14] leading to easy breakdown in its resistance. Although, some few plants which inherited the two genes were totally resistant. This is similar to what Muhalet et al. [15] and Peloso et al. [16] also reported that duplicate dominant genes were responsible for anthracnose resistance in some bean crosses.

Molecular markers have been developed for many diseases resistance genes and these markers have been successfully used to develop improved common bean cultivars and germplasm [17]. About 10 different anthracnose resistance genes (designated with $\mathrm{Co}$ symbol) have been characterized and markers linked to most of these resistance loci have been identified [18] [19] [20] [21].

In this study, two SCAR markers SAB 3 and SBB14 linked to anthracnose resistance genes $\mathrm{Co}-4^{2}$ and $\mathrm{Co}-5$ were screened in a recurrent and donor parents as well as in $\mathrm{BC}_{2} \mathrm{~F}_{1}$ population developed for anthracnose resistance. Only twenty six $\mathrm{BC}_{2} \mathrm{~F}_{1}$ plants inherited the target genes; Nine plants had the two resistance genes $\mathrm{Co}-4^{2}$ and $\mathrm{Co}-5$ and 17 plants inherited either $\mathrm{Co}-4^{2}$ or $\mathrm{Co}-5$ genes. The observed ratio of resistant to susceptible plants was significantly different from the expected ratio. This might be due to the screening of non-homozygous $\mathrm{BC}_{2} \mathrm{~F}_{1}$ plants as all the plants were heterozygous for $\mathrm{Co}-4^{2}$ gene. Servin et al. [22] recommended crossing the root genotype with a blank parent to obtain a genotype carrying all favourable alleles in coupling phase then self-pollinate the $F_{1}$ to produce the ideotype with fixed target genes in one generation.

Based on the results obtained from the present study, the findings promise that it is possible to improve common bean for anthracnose and Pythium root rot diseases resistance in one cultivar. Presence of SCAR-markers, SAB3 and SBB14, in the developed resistant population revealed a successful resistance transfer of anthracnose resistance genes using a MAS backcrossing program. 


\section{Acknowledgements}

Rwanda Agriculture and Animal Resources Development Board (RAB) and Kirkhouse Trust are acknowledged for their support and facilities.

\section{Conflicts of Interest}

The authors declare no conflicts of interest regarding the publication of this paper.

\section{References}

[1] Singh, S.P. and Schwartz, H.F. (2010) Breeding Common Bean for Resistance to Diseases: A Review. Crop Science, 50, 2199-2223. https://doi.org/10.2135/cropsci2009.03.0163

[2] Melotto, M., Balardin, R.S. and Kelly, J.D. (2000) Host-Pathogen Interaction and Variability of Colletotrichum lindemuthianum. In: Prusky, D., Freeman, S. and Dickman, M.B., Eds., Colletotrichum Host Specificity, Pathology, and Host-Pathogen Interaction, APS Press, St. Paul, 346-361.

[3] Pastor-Corrales, M.A. and Tu, J.C. (1989) Anthracnose. In: Schwartz, H.F. and Pastor-Corrales, M.A., Eds., Bean Production Problems in the Tropics, 2nd Edition, CIAT, Cali, 77-104.

[4] Otsyula, R.M., Buruchara, R.A., Mahuku, G. and Rubaihayo, P. (2003) Inheritance and Transfer of Root Rots (Pythium) Resistance to Bean Genotypes. African Crop Science, 6, 295-298.

[5] Kelly, J.D. and Vallejo, V.A. (2004) A Comprehensive Review of the Major Genes Conditioning Resistance to Anthracnose in Common Bean. HortScience, 39, 1196-1207. https://doi.org/10.21273/HORTSCI.39.6.1196

[6] Allen, D.J., Burachara, R.A. and Smithson, J.B. (1998) Diseases of Common Bean. In: Allen, D.J. and Lenne, J.M., Eds., The Pathology of Food and Pasture Legumes, CAB International, Wallingford, UK, 179-265.

[7] Nzungize, J., Gepts, P., Buruchara, R.A., Male, A., Ragama, P., Busogoro, J.P. and Baudoin, J.P. (2011) Introgression of Pythium Root Rot Resistance Gene into Rwandan Susceptible Common Bean Cultivars. African Journal of Plant Science, 5, 193-200.

[8] Van Schoonhoven, A. and Pastor-Corrales, M.A. (1987) Standard System for the Evaluation of Bean Germplasm. Centro International Agricultural Tropical, Cali, 23 p.

[9] Luis, S.Z. and Vaillant, B. (2012) Rapid Risk and Capacities Assessment and Livelihoods Profiling in Nyabihu, Musanze and Burera Districts Affected by Floods and Landslides, $13 \mathrm{p}$.

[10] Mbogori, M.N., Kimani, M., Kuria, A., Lagat, M. and Danson, J.W. (2006) Optimisation of FTA Technologies for Large Scale Plant DNA Isolation for Use in Marker Assisted Selection. Biotechnology Centre Kenya Agricultural Research Institute, Kenya. African Journal of Biotechnology, 5, 963-969.

[11] Hittalmani, S., Parco, A., Mew, T.V., Zeigler, R.S. and Huang, N. (2000) Fine Mapping and DNA Marker-Assisted Pyramiding of the Three Major Genes for Blast Resistance in Rice. Theoretical and Applied Genetics, 100, 1121-1128. https://doi.org/10.1007/s001220051395

[12] Balardin, R.S. and Kelly, J.D. (1998) Interaction among Races of Colletotrichum lindemuthianum and Diversity in Phaseolus vulgaris. Journal of the American Soci- 
ety for Horticultural Science, 123, 1038-1047. https://doi.org/10.21273/JASHS.123.6.1038

[13] Mahuku, G.S., Jara, C., Cajiao, C. and Beebe, S. (2002) Source of Resistance to Colletotrichum lindemuthianum in the Secondary Gene Pool of Phaseolus vulgaris and in Crosses of Primary and Secondary Gene Pools. Plant Disease, 86, 1383-1387. https://doi.org/10.1094/PDIS.2002.86.12.1383

[14] CIAT (1997) Annual Report/CIAT. Rapport Annual 1997. https://iifiir.org/en/fridoc/ciat-1997-annual-report-2119.

[15] Muhalet, C.S., Adams, M.W., Saettler, A. and Gadheri, G. (1981) Genetic System for the Reaction of Field Beans to Beta, Gamma and Delta Races of Colletotrichum lindemuthianum. Journal of the American Society for Horticultural Science, 106, 601-604.

[16] Pelosso, M.J., Del Cardoso, A.A., Vieira, C., Sarava, C. and Zimmerman, M.J.O. (1989) Genetic System for Reaction of Phaseolus vulgaris to the BA-2 (alpha) Race of Colletotrichum lindemuthianum. Brazilian Journal of Genetics, 12, 313-318.

[17] Kelly, J.D. and Miklas, P.N. (1998) The Role of RAPD Markers in Breeding for Disease Resistance in Common Bean. Molecular Breeding, 4, 1-11.

[18] Young, R.A. and Kelly, J.D. (1997) RAPD Markers Linked to Three Major Anthracnose Resistance Genes in Common Bean. Crop Science, 37, 940-946. https://doi.org/10.2135/cropsci1997.0011183X003700030039x

[19] Young, R.A., Melotto, M., Nodari, R.O. and Kelly, J.D. (1998) Marker Assisted Dissection of Oligogenic Anthracnose Resistance in the Common Bean Cultivar, “G2333". Theoretical and Applied Genetics, 96, 87-94. https://doi.org/10.1007/s001220050713

[20] Geffroy, V., Sicard, D., De Oliveira, J.C., Sévignac, M., Cohen, M., Gepts, P., Neema, C., Langin, T. and Dron, M. (1999) Identification of an Ancestral Resistance Gene Cluster Involved in the Coevolution Process between Phaseolus vulgaris and Its Fungal Pathogen Colletotrichum lindemuthianum. Molecular Plant-Microbe Interactions, 12, 774-784. https://doi.org/10.1094/MPMI.1999.12.9.774

[21] Vallejo, V. and Kelly, J.D. (2001) Development of SCAR Markers Linked to the Co-5 Locus in Common Bean. Annual Report of the Bean Improvement Cooperative, 44, 121-122.

[22] Servin, B., Martin, C.O., Mezard, M. and Hospital, F. (2004) Toward a Theory of Marker-Assisted Gene Pyramiding. Genetics, 168, 513-523.

https://doi.org/10.1534/genetics.103.023358 